PART 2

Urban Communities and Non-Urban Sites 
Elisabeth Gruber - 9789004315693

Downloaded from Brill.come4/26/2023 10:58:21AM via free access 


\title{
The City as Commune
}

\author{
Elisabeth Gruber
}

\section{Introduction}

Throughout the regions of medieval Europe as well as in South Arabia, urban settlements played an important role in the political, economic and social development of a landscape. These settlements not only had infrastructural or centralizing functions but also provided opportunities for as well as constraints on the coexistence of several groups with specific qualities, forms and practices of belonging, togetherness, and solidarity. ${ }^{1}$ Within the Visions of Community project (VISCOM), we investigate various forms of identification and belonging in different settings of coexistence and thus ask to what extent dense settlements like European urban communities or South-Arabian non-urban sites can be considered as communities. ${ }^{2}$ We are aware that we are comparing communities under different legal, economic, religious, political, and also social conditions. But we are also interested in developing shared criteria to establish how and by what means these forms of settlement provided the framework for the formation of coexisting but also conflicting groups in late medieval times. ${ }^{3}$

In this paper I first want to examine the legal basis on which cities in the Holy Roman Empire can be typologically understood as urban communities. Civic rights and duties, confirmed by a civic oath, had long been held to be the most significant elements of formal belonging which entitled a person to participate in this thus politically defined type of community. In a second step I will look at concrete forms and practices of belonging, using the example of towns and cities situated in the Central European regions of Austria and Bohemia. My research shows that kinship and religious affiliations are useful categories to deepen our understanding of what held these urban communities together beyond legal issues.

1 On terminological issues see Lutter, "Social Groups", 48.

2 Within the visсом project a transversal working group comprising Eirik Hovden, Johann Heiss (Po3), Fabian Kümmeler (Po7), Elisabeth Gruber and Judit Majorossy (Po6) has been established.

Lutter, "Comparative Approaches".

(C) ELISABETH GRUBER, 2016 | DOI 10.1163/9789004315693_006

This is an open access chapter distributed under the terms of the Creative Commons Attribution- 


\section{Civic Right and Civic Oath}

Starting from the perspective of legal history, historians of urban history have discussed at length and in detail what can be described as a city in the Christian West. For a long time, the predominant criteria used to distinguish the city from its hinterland were the existence of a city wall and princely privileges. In this scholarly tradition walls were not only seen to serve defensive purposes, but also to demarcate a defined sphere of urban rights separating it from the surrounding countryside structured in terms of "feudalism". ${ }^{4}$ Since then, many studies with different approaches and research perspectives have shown that the criteria for defining a city are multifaceted, which has resulted in a kind of working definition that most researchers have meanwhile basically agreed upon..$^{5}$ A settlement's relatively dense population, broad range of economic functions, complex social and political structures, cultural and economic influence often extending beyond the spatial and mental borders of the settlement, and distinctive architectural environment including public buildings and public space describe this particular form of living together in a complex manner. ${ }^{6}$ Differences in time and region, and the relation with the city's surrounding areas also play an important part in the description and characterization of European medieval cities.

In any case, however, the existence of an urban community is an indispensable requirement for any definition of a city. What follows now should help to understand in more detail the social changes which were decisive for the establishment of urban communities in the Holy Roman Empire. Where are the origins of this new development that simultaneously also led to a more nuanced understanding of personal freedom, political participation and selfdetermination of those people who participated in it - at least in a conceptual manner? What ideas and requirements were associated with the formation of these communities?

4 It was Edith Ennen who described the late medieval city as a clearly defined space of people and activities: Ennen, Stadt des Mittelalters. The topos of urban and rural divide has its roots in antiquity, but the sociological discourse emphasizing the demarcation of the city from its hinterland occurred in the 19th century. Later, Max Weber argued that the Western city as a distinct space was among other criteria characterized by its corporative capacity and autonomy. See Arnade/Howell/Simons, "Fertile Spaces", 530. Also the concept of feudalism has been thoroughly criticized and revised since then, cf. the classic study by Susan Reynolds: Reynolds, The Middle Ages without feudalism.

5 For the research discussion see Isenmann, Die deutsche Stadt, 39-52. Arnade/Howell/Simons, "Fertile Space", 534-35, with a focus on urban space.

6 Clark, "Introduction", 4. For an overview see Pauly/Scheutz, "Space and History", 22-28. 
It is a matter of definition when we can begin to speak of urban settlements in Central Europe north of the Alps, but there are good reasons to place them in the 1oth century in the case of episcopal sees with attached artisans' and merchants' settlements, especially those with roots in late antiquity, such as Trier, Köln (Cologne), Augsburg or Regensburg (Ratisbone). When investigating the basic principles of cooperation and the conditions which were important for the political emancipation of these cities during the 1oth and nth centuries, we have to keep in mind some aspects of broader societal change. ${ }^{7}$ From the 11th century onwards, sources begin to talk of conflicts between people living in dense settlements (often near episcopal sees) and their lords, because the former developed their own organization and were no longer willing to submit to all of their lords' demands. We learn from source material that by the mid 12th century the word commune was coming into common use to describe urban organization and communities and their government. Its use in urban contexts may derive from communia - meaning common property. Occasionally these changes took place during conflicts between town communities and their bishops or other local lords-but this was by no means a necessary pattern. ${ }^{8}$ An increase in population, which promoted the rapid growth of settlements since the turn of the millennium, the recovery of trade relations and the differentiation of crafts and commerce, as well as the weakening of manorial ties have been argued as important conditions for this development. ${ }^{9}$

During the 11th and 12th centuries the inhabitants of towns in the Holy Roman Empire north of the Alps were not, as mostly in Italy, persons of personal "free" status, but legally "unfree" to different degrees. Personal freedom and legal liberties were often obtained from the respective lords in phases of conflict and/or by negotiation. To promote frictionless living in an urban context, it was necessary for the inhabitants to acquire and keep the settlement of conflicts in their own hands, since they knew their needs and ways. This meant pushing back or taking over the lord's jurisdiction and - with less successacquiring judicially exempt spheres in the townspeople's competence, such as the municipal jurisdiction or the right to collect taxes. Research for a long time considered emancipation from a legally unfree status to be a crucial requirement for the formation of municipal institutions and economic independence,

7 Schulz, Kommunale Aufstände, 5-11; id., "Stadtentwicklung", 73-93; id., "Freiheitsrechte", 461-84; id., "Urbanisierung", 147-72; Diestelkamp, "Freiheit”, 485-510.

8 Reynolds, Kingdoms, 170-71; Steiner, Klöster; Isenmann, "Notion”, 107-48; Haverkamp, "Bruderschaften", 153-92.

9 Schulz, Aufstände. 
all of which were defining marks of urbanity during the 12 th and 13 th centuries. ${ }^{10}$ For example, in his autobiography the Benedictine monk Guibert de Nogent (1055-1124) reported on a town's uprising against its bishop in the French city of Laon. Although the story mainly deals with the bishop's corrupt character, it is the burghers' conspiracy that forms the framework for the events. "Now Commune is a new and a bad name", Guibert de Nogent concluded his description of this new situation, where "the people seizing on this opportunity for freeing themselves gathered huge sums of money to fill the gaping mouths of so many greedy men".11 What kind of development is Guibert's cause for complaint? During this period, the social order in most western regions of Europe was based — at least theoretically — on manorialism: free aristocrats lent property of their manor to unfree peasants. They offered them protection and in return were compensated with services and taxes. The manorial system, based on agriculture, formed the backbone and power base for the king, the nobility, and ecclesiastical institutions. ${ }^{12}$ Concerning legal matter: the familia of the manorial lord comprised his next of kin as well as all servants and dependants, who were - at least theoretically — completely subject to his power. How then did it come about that "unfree" persons living in towns (contemporary sources call them manicipia, servi; ancillae, homines ecclesie, litones, censuales; tributarii) were legally freed from personal bonds and commitments?

The historian Knut Schulz, who dealt with this question for the Germanspeaking regions, typologically defines three stages of development. These differ depending on their regional and temporal contexts, and may be clearly observable in some situations, hardly visible in others. ${ }^{13}$ Schulz sees the first stage of this development in the free availability of the town's own workforce, and therefore a chance for a certain self-determination of the commune. This model applies particularly to two groups of in this specific sense unfree persons: censuales and ministeriales. Censuales are individuals obligated to pay contributions and whose status is defined by membership in the manorial familia and a duty-based attachment to the lord, at least according to the extant sources, which mostly represent an ecclesiastical perspective. This bond consisted in annual fees: per capita duty and wax duty, as well as a duty in case of death (Besthaupt and Bestkleid), payable from the deceased person's inheritance. Marriage regulations prohibited unions with members of other

\footnotetext{
$10 \quad$ Schulz, "Freiheitsrechte", 461.

11 Archambault, ed., A Monk's Confession, 146; Kaiser, "Guibert de Nogent", 121-58; Boone, "Cities", 329-49.

12 Rösener, "Grundherrschaft", cols. 1746-47.

13 Schulz, "Freiheitsrechte", 462-63.
} 
lords' familiae and threatened transgressions with severe sanctions. From the 12th century onwards, the status of censuality and bondage drifted apart, leaving censuales bound only by their financial obligations; in some cases, they gained exemption from personal services and the right of unlimited mobility. This created many new opportunities and led to considerable social differences among censuales. The establishment of distinctive rights and obligations (Zensualenrecht) in the 12th century supported the formation of a separate area of law and justice. In some regions, especially in southern Germany, the transfer of persons under this type of law can be documented by entries into a book of deeds, which were not confirmed with single-sheet charters but only by the entry. Both individuals and families of free and unfree origin were able to submit themselves to the protection of religious houses. It is striking that the legal institution of censuality increasingly seems to have developed especially in landscapes that were dominated by large ecclesiastical lordships. ${ }^{14}$ However, it must also be emphasized that this impression mainly results from the fact that written records for lay lords are mostly lacking in this period.

Another milestone on the way to a "self-determined" urban society is the granting of the free and unrestricted right to inherit and to marry. ${ }^{15}$ This applies especially to the group of ministeriales, a large majority of nobility, legally unfree and with a wide variety of duties and restrictions towards their current lord. They remained integrated into the liege lord's familia, though some of them settled in towns as well. Over time, they took over important functions within the municipal administration due to their closeness to the town's lord. While restrictions on marriage and inheritance often remained in force for them, as a result of their right to obtain fiefs, social advancement was more likely to be possible for this group. In a number of cases, its members can be shown to have been incorporated, at least to some extent, into the urban community, and in some cities they were actually part of the citizenry as a political body. ${ }^{16}$ Due to a lack of sources, generalization based on single cases is hardly possible. Still, in many charters, citizens and knights, cives and milites, are named next to each other. Importantly, social differences could mostly be

\footnotetext{
14 Diestelkamp, "Freiheit", 492-93.

15 Thus, for example, emperor Henry V granted the inhabitants of Speyer (1111) and Worms (1114) the freedom from the death levy, which in practice meant a release from the consequences, as stated by inheritance and matrimonial law, of a marriage outside the group. See Schulz, "Zensualen", cols. 530-33.

16 For Austria, for example in Laa/Thaya, see Weltin, "Stadtministerialität", 9-23; for Steyr, Klosterneuburg, Krems, Tulln, Ybbs, and St Pölten, see Weigl, Materialien; id. "Städte und Adel", 74-100.
} 
levelled by a group consciousness created through this new independent legal domain of a commune.

As the last remnants of personal subjection began to disappear during the 11th century, members of the urban elite joined together by means of the legal instrument of a "civic oath" which committed them to loyalty and obedience to the lord of the town, but also to the urban community as such. ${ }^{17}$ Thus communities gradually emerged which were in the first place composed of men with equal rights - at least theoretically — and united by obligations to each other. This oath among peers was explicitly aimed at establishing a long-term community, based on peace and law, in order to secure matters of common interest against neighbours inside and outside the town as well as against competitors and superiors. Ideally, an urban community was able to develop an institutional, cultural, and social life of its own with limited influence from outside, often preceded by serious conflicts between urban community and its lord. In these processes, the urban communities gained (sometimes limited) rights of political self-organization and decision-making.

It is important to note that the 11th-century church reform resulting from and accompanying the struggle between imperial and papal powers over hegemony in Europe, provided at least part of the theoretical—as well as the political—framework for this municipal striving for emancipation. Ecclesiastical concepts of community may well have joined hands with the political and judicial group-consciousness of peer communities, such as vassals, ministerials and, of course, townspeople. ${ }^{18}$ The concept of confraternities-in a religious sense or else addressing fraternal support between secular or economic groups with common interests-finds its expression in the concern for the salvation of souls. ${ }^{19}$ As safeguards of the citizens' salvation, ecclesiastical endowments as well as monastic or hospital foundations had their functions in the earthly present as well as with regard to the afterlife. ${ }^{20}$ In the course of these reforms, sacramental and pastoral administrators became central for the city's community. During the 12th century, for example, this becomes evident by the topographic connection of main street, market place, and church. ${ }^{21}$ Even the constitutional bodies of the cities could organize themselves in

\footnotetext{
17 Isenmann, Die deutsche Stadt, 146-47.

18 Schneidmüller, Weinfurter, "Ordnungskonfigurationen", 7-18; Haverkamp, "Bruderschaften"; cf. also Lutter, "Vita Communis", in this volume.

19 Oexle, "Gegenwart", 19-77; examples in Lutter, "Vita Communis", O'Riain, "The Schottenklöster in the World", in this volume.

20 Jakobs, "Stadtgemeinde", 28.

21 Jakobs, "Stadtgemeinde", 29.
} 
fraternities to limit the number of persons who were entitled to hold a leadership position. ${ }^{22}$

To establish and maintain the townspeople's peaceful coexistence, moral concepts of behaviour and political association were developed to provideat least in theory - the concern for the common good (bonum commune). Common property of a city and its written representations in books of municipal statutes preserved a public benefit. ${ }^{23}$

In most Central European regions, this development took place later, during the 12th and 13th centuries, when many new towns were founded, foremost, but by no means exclusively, in the eastern regions of the Holy Roman Empire, and mostly as a means of consolidating the territorial sovereignty of the regional princes. In many cases, however, in these regions the established pattern of community-building, which was based on the swearing of civic oaths by the members of the functional and social urban elites, was used right from the beginnings of these urban settlements, according to the available sources. ${ }^{24}$ With the establishment of a certain degree of internal organization, forms of communal life and public representation developed as well. Different types of municipal authority and city council stood for the external representation and institutionalization of these communities. Whereas urban space embraced different social groups that were often closely related to each other, accepted norms and rules-which led to a more formal and longer-lasting differentiation between them - were, in the course of time, gradually established explicitly, or else evolved implicitly.

\section{Urban Communities in the Duchies of Austria and Styria: Towns and their Sovereign}

In recent research, cities have increasingly been seen in a wider context of urban-rural relationships. In order to give a more nuanced picture of the quality of specific urban communities, their importance for a particular region and its structure has to be determined. ${ }^{25}$ In Central Europe, and especially in the kingdoms of Bohemia and Hungary as well as in the duchies of Austria and

\footnotetext{
22 Jakobs, "Stadtgemeinde", 26.

23 Isenmann, "Notion", 109-10; id., Die deutsche Stadt, 229-30; Rogge, Politisches Handeln.

24 Csendes, "St. Pölten"; Csendes, Stadtrechtsprivileg; Gutkas, "Städtewesen".

25 Herbert Knittler's contribution focuses on princely towns of the Duchy of Austria in late medieval and early modern times: Knittler, "Städtelandschaften", 111-33.
} 
Styria, the foundation of towns and cities was closely related to the establishment and consolidation of territorial sovereignty. Princely territories needed to be stabilized not only in military and political ways, but also by ecclesiastical and infrastructural means. Many towns that were founded along trade routes in times of territorial expansion illustrate the close connection between these factors. ${ }^{26}$

How much and in what ways did the development of these towns differ from that in the core regions of the Holy Roman Empire, and why were these towns at the same time motivated to sustain their own community interests as well as to support the strategies of their lords in various ways? Although preserved only as a copy in a cartulary, the earliest known charter with provisions for an Austrian town is the one for St Pölten. It was issued in 1159 by the town's lord, Bishop Konrad of Passau, and regulates procedures in law courts in favour of the burghers, the burgenses of St Pölten. ${ }^{27}$ It grants them the right to use a responsor (vorsprech) in court, prohibits the use of ordeals in cases against them, and declares accusations in matters of property and mortgage brought forward by outsiders against a burgess as invalid if not supported by the testimony of other burgenses. A charter of Leopold VI for the town of Zwettl (1200) refers to the rights previously granted to Chremenses urbani nostri, "our townspeople in Krems". Obviously, these townspeople were already perceived and addressed as a new and defineable distinct social group. ${ }^{28}$ These acts of codification and granting of rights in writing are closely related to a process of increasing literacy. The urban communities' increasing confidence in literacy also played an important role. The reorganization of the judicial competences of the town's judge was a notable step towards the establishment of an urban community. ${ }^{29}$ The formation of a law court consisting of members of the urban elite together with the judge could—but did not necessarily need to-reduce the influence of the lord who owned the town.

This can be shown by the municipal law of Vienna from $1221,{ }^{30}$ where the close bonds between the lord and his citizens are emphasized. Medieval Vienna was built on the ancient remains of a Roman military camp, Vindobona.

26 On the concept of urban landscapes in the European context see Gräf/Keller, eds., "Städtelandschaft", esp. for Bohemia and Moravia see Žemlička, "Böhmen" in the same volume.

27 Katzinger, ed., Elenchus 3/1, 20-21 no. 24; see also Dienst, "Privileg”, 79-86.

28 Fichtenau, Zöllner, eds., Urkundenbuch Babenberger, 1:117 no. 86; Csendes, "St. Pölten", 79-84.

29 Schulz, "Familia", 476.

3o Edition and comment: Csendes, Stadtrechtsprivileg. 
Around the turn of the millennium there are signs of the development of an early, still very modest medieval settlement. Only from the beginning of the 12th century do an increasing number of sources allow us to trace the city's development with any certainty. In this period, the Austrian princes were able to consolidate their position and relocated their residence to Vienna. ${ }^{31}$ As a result of losing the Duchy of Bavaria, the Babenberg dukes gained the dukedom for Austria. Consequently, their former residence in Regensburg became exemplary for the shaping of the new Austrian-now ducal-residence of Vienna. In some important respects, however, Vienna differs from its model. While at the beginning of the 1oth century Regensburg was an episcopal see,

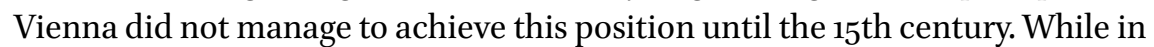
Regensburg it was the episcopal infrastructure that greatly influenced the legal development of the city, in Vienna it was the duke who chiefly affected the legal and, as a result, also the social and political development of the city. ${ }^{32}$ Nevertheless, the municipal rights of Vienna, formally granted by the Austrian duke in 1221, answered the demands of the city's burghers, who wanted to obtain the confirmation of their rights. These included the establishment of a civic council, which was obliged to provide for the city's reputation, and benefit: de universis, que ad honorem et utilitatem civitatis pertinent. ${ }^{33}$

By the beginning of the 13th century the Austrian dukes had founded several new towns in the Danube region or acquired existing ones to establish their reign in the Duchy of Austria. Most of these towns - 50 privileged with specific urban rights-were small, with an average of 2,000 to 3,000 inhabitants. These estimates indicate an aproximate number of inhabitants, but by no means the whole group of members of the political community. In this sense it is useful to address them as towns and not as cities. ${ }^{34}$ Although the Austrian towns were formed only by small communities, they played an important role for the sovereign's policy. From the beginning of his rule in the Duchy of Austria, the Bohemian king Přemysl Ottokar II (1253-1278 King of Bohemia, 1251/1260-1278 Duke of Austria and Styria) used the existing infrastructure of the towns. The Upper Austrian city of Freistadt, for example, is situated on the road from Bohemia to the Danube and was the first town King Ottokar visited during his

$31 \quad$ For this see Csendes, "Grundlagen", 69-74; detailed material on Vienna collected in Lohrmann/Opll, eds., Regesten zur Frühgeschichte von Wien; forthcoming: Gruber/Zapke, Medieval Vienna.

32 Csendes, "Babenbergerresidenzen", 163-71; Frauenknecht, "Bischof", 688-709; for Regensburg see Wanderwitz, "Regensburg”, 43-54; Schmid, “Herrschaftsträger”, 45-56.

33 Csendes, Stadtrechtsprivileg, 74-75.

34 Knittler, "Problem", 91; for an overview see: Opll, "Stadtgeschichtsforschung". 
journey through the Duchy in 1251. In the first ten years of his rule, he stayed six times in Linz, a town with a Danube crossing. He also held his first diet in a town, namely Korneuburg on the Danube near Vienna. ${ }^{35}$ We know about this sojourn from deeds and privileges he issued there. The noble ministeriality supporting the king was not the only one present at the diets. The urban ministerials who controlled important towns also supported Ottokar as new ruler. These included, for instance, the Tröstel family from Linz, the Polheims in Wels, and Dietmar of Steyr, all of whom were loyal supporters of Ottokar's policies. ${ }^{36}$

But also in the eastern regions of the reign towns secured the borders in local and regional conflicts. The Lower-Austrian town of Marchegg was founded as a military base and assembly point for Austro-Bohemian forces fighting the Hungarians. Moreover, cities like the Hungarian town HungarianHradisch, as well as Radkersburg/Mur, Bruck/Mur and Leoben in the Duchy of Styria, were founded and their urban development supported in order to ensure the protection of borders and transport routes. ${ }^{37}$

The reign of the Bohemian king also prompted new accents in the internal developments of Austrian towns. With the Landfrieden, the Pax Austriaca (1251), judicial districts comprising a town and its closest surroundings were exempted from the earlier, larger districts under the administration of ministerials or noblemen, thus giving birth to a genuine office, the town judges. ${ }^{38}$ Like some of the most powerful ministerials devoted to the new ruler, they exercised the office on behalf of the lord, but soon the citizens became interested in - and succeeded in obtaining - the position for one of their own. Characteristically, a Viennese privilege from the mid-13th century distinguished the bonus homo as someone who non est homo nobilis. Here, a civic group is contrasted to a prominent noble elite. In the later 13th century, citizens who were recognizable as knights (milites) or land-owning citizens (cives) —or even both in the same person-would emerge from this group. ${ }^{39} \mathrm{It}$ was Rudolf I of Habsburg who declared all citizens of Vienna eligible to hold fiefs. Thereafter, Viennese knights' and citizens' rights of marriage and inheritance were hardly restricted at all, and both were entitled to receive fiefs. ${ }^{40}$ They formed the elite of the late medieval city of Vienna. This process was

Zauner, "Ottokar II. Přemysl”, 1-72, with material.

36 Gutkas, "Städtepolitik", 107-25.

37 Pferschy, “Ottokar II. Přemysl”, 73-91.

38 Weltin, "Landesherr", 146-54.

39 Csendes, Stadtrechtsprivileg, 20.

40 Csendes, Stadtrechtsprivileg, 70-71. 
completed during the course of the 14th century. These entangled legal and social developments provided the framework for the formation of an urban elite in the various provincial and manorial towns in the duchies of Austria and Styria. Its members tried to secure their legal, financial, infrastructural, political, public, and private position within the urban community, but also towards the town's lord.

But what were the expressions of belonging, practices of community that characterized different social groups within an urban community? What influence do the various religious communities (parishes, monasteries, confraternities) have on the formation of groups within the city? How do they affect internal coherence, established norms and institutions?

In the second part of this contribution I will discuss different forms of bonds that were important for the internal cohesion and external representation of late medieval urban elites: kinship and urban memoria.

\section{Practices of Urban Communities: Kinship and Donation}

One of the most important cohesive elements in late medieval society, and therefore also in urban society, was kinship. It represented a key principle of urban society ${ }^{41}$ and could be used as an interface bridging different interests, securing economic friendships or confirming existing ties. ${ }^{42}$ Although noble family structures have been a subject of research for centuries, the analysis of medieval urban family structures has long been comparatively neglected by historical research. Apart from the limitations posed by the sources, there are also various conceptual reasons for this, as Simon Teuscher observed. ${ }^{43}$ For researchers who considered medieval urban society as a "pioneer of modernization" and tried to fit it into modern social frameworks, a traditional concept like kinship did not fit the pattern. Others argue that while the noble self-image in the Middle Ages produced different forms of genealogical description and even gained additional importance in the modern era, one is faced with a completely different tradition when exploring the urban elites. Earlier perceptions claimed that the strong ties of coherent kinship groups represented a more conservative element, which had to be broken by the modern forms of city

\footnotetext{
41 Seidel, Freunde, 310; Blockmans, "Constructing", 575-77.

42 Jussen, "Verwandtschaftsforschung", cf. 304-12; Teuscher, Soziabilität und Politik, 65; Sabean, Teuscher, "Kinship", 1-13, 24-26; Signori, Gütergemeinschaft, cf. 57-123.

43 Teuscher, "Kinship", 76.
} 
government. ${ }^{44}$ Both estimations led to a disregard of the forms, role, and usage of kin relations in the urban context, Teuscher argues. Recent research, however, has shown that kin relations depended on a wide range of exchange and communication: patterns of inheritance and succession, systems of marriage alliance, circulation of goods, patterned practices of relationship, and cultural representations of kinship can be observed both in noble and urban contexts. ${ }^{45}$

A glance at the written sources of late medieval towns in the region of Austria raises more questions than it provides answers. In most Austrian cases, neither marriage agreements nor any other series of sources recording precise family relations can be found. Kinship connections have to be reconstructed from hints in legal and administrative records. It is rarely possible to trace a family genealogy for more than two or three generations, while due to the number and types of sources this is more practicable for noble families. ${ }^{46}$ What kind of source material can be used to answer our question? What are the types of relationships formulated in the available sources? The Archive of the City of Vienna, for instance, includes records relating to sales of townhouses to married couples. From these documents we learn both the names of the sellers and the buyers, as well as the location of the property and any obligations upon it. Thus, the texts give relevant, but not always precise, details of kin relations and inheritance rights, which were regulated by the municipal law. ${ }^{47}$ For example, a certain Leopold and his wife Katharina together sold their house, which they had built with their own means at one of the main gates of Vienna, to a Viennese burgher, his wife Elisabeth, and their heirs. ${ }^{48}$ These formulations are typical as is the lack of personal data beyond the protagonists given names.

The terms and clauses used relate to the legal protection of ownership in case of death, but also to the rights of ownership during marriage. The heirs mentioned can be understood both as the buying couple's children and, if there are no children, as the closest relatives of each of the spouses as their respective heirs. This form of legal protection of the transfer of ownership

44 Teuscher, "Kinship", 77.

45 Sabean, Teuscher, "Kinship", 6-10; for the Low Countries see Howell, Marriage Exchange; Keil, ed., Besitz, with examples from Prague and Dalmatia; for the German nobility Spieß, Familie; for South Europe recently Wessell Lightfoot, Marriage.

46 Zajic, Memoria, 15-17; Scheibelreiter, "Typologie”, cf. 292-310.

47 Lentze, "Wiener Testamentsrecht"; Neschwara, "Rechtsformen", 131-47.

48 "dazwir mit einander eraribait und gechaufft haben, dem erbn mann Pauln dem Rostauscher ze Wienn, vrown Elsbeten, seiner hausvrown und ir baider erben", see: Uhlirz, ed., Quellen, 176, no. 735 . 
within the family appears interesting insofar as — as far as the source material allows an assessment-it obviously had to be made explicit. There are similar records in the various municipal archives of the Duchy of Austria, where systematic property registers are only available from the late $15^{\text {th }}$ and 16 th centuries onward. ${ }^{49}$ The organization of property and its monopolization in the hands of the family is closely linked to the organization, representation, and reconfiguration of kinship and family practices. Kinship and property were two fundamental categories of social hierarchy and economic order. Economic and political contacts and commitments were strengthened, secured and extended via multiple forms of kinship. ${ }^{50}$ Marriage was used to establish, manifest, and secure one's own social but also economic standing. ${ }^{51}$ In this practical sense, urban community was forged and maintained by family ties, maintaining economic or political associations in a quite cohesive manner.

Another sign of the protection not only of family structures but also community-related internal balances, in this case by spiritual means, can be seen in the prayer communities centred on commemorative masses endowed with pious donations. During the 14th and $15^{\text {th }}$ centuries, this type of community increasingly turned into an instrument of urban memoria. ${ }^{52}$ These charitable practices cannot be explained by the individual motivations of benefactors alone, but must also be interpreted as conscious as well as habitual, active as well as socially embedded actions and reactions of individual persons and groups answering contemporary needs. ${ }^{53}$ From the benefactor's perspective, one of the most important motives was the durability of his or her donation. Thus social and legal strategies to secure an endowment's long-term duration were central. Chapel and altar donations, anniversary and memorial donations, as well as donations of liturgical objects and alms only fulfilled their purpose of long-term, and even eternal, memory if the mechanisms of binding social ties and responsibilities were kept in place. Corresponding to this, the attitudes and social behaviour of individuals and groups towards the dead to whom they were connected by acquaintance, friendship or kinship were especially significant.

49 For Vienna e.g. Lohrmann, Grundbücher.

50 Jancke and Schläppi, "Ökonomie sozialer Beziehungen", 94-95; Bourdieu, "The forms of capital", 251.

$51 \quad$ Signori, "Gütergemeinschaft", 13-53.

$5^{2}$ The classical study is Chiffoleau, La Comptabilité; for case studies on urban memoria see for Cologne Seidel, Freunde, 56-121; for Bratislava, Sopron and Presov see Szende, "Otthon a városban"; for Vienna see Pohl-Resl, "Family"; for urban and noble memoria in the Austrian lands see Zajic, Memoria; Gruber, "Memoria”; id. "Handlungsspielräume”.

The classical study is Oexle, "Gegenwart der Toten", 20-77. 
Research into medieval donations, which has been stimulated considerably by the ground-breaking work of Otto G. Oexle and Michael Borgolte, ${ }^{54}$ covers almost all fields of human memorial behaviour. Within this tradition, courtly as well as monastic and urban spheres have been-and still are-the object of research. For the region of Lower Austria, for example, publications on Korneuburg, Krems, Tulln, Vienna, and Wiener Neustadt concern various aspects of citizens' memorial economies. ${ }^{55}$ Each town's internal organization was already well established by the $15^{\text {th }}$ century, when a significant documentation of memorial practice starts to become available: town magistrates, mayors and town councils formed the functional and for most of the time also the economic elite of the town. According to the town's geographic location, they had developed different economic and political interests, and these had a great impact on the town's profile. The location along important trade routes, close to mining resources or a strategic positioning, for example in border regions of the duchy, had influenced the development of the towns, as had the interaction between the towns and their respective lords. However, the source material is inconsistent and passed on coincidently. In comparison to other European towns like Constance, Paris or Stralsund (just to mention some), where series of last wills are preserved that allow a dense description of people's final wishes, the situation in our region under review is characterized by the lack of serial data. ${ }^{56}$ Thus a comparative analysis of selected towns relating to available source material could be a promising starting point to emphasize the interplay between kin relations, family memoria and mechanisms of urban-based internal cohesion as well as external connection. I want to focus on urban memorial culture using the example of an entire region, instead of single towns. Within the region of South Bohemia and the borderlands of Austria three towns played an important role during the late Middle Ages: the Upper Austrian town of Freistadt and the two South Bohemian towns of Česky Krumlov/Krumau and Česky Budějovice/Budweis. ${ }^{57}$ They constantly remained in touch with each other, especially in terms of economy and infrastructure. Two of these, Freistadt and Budweis, were founded by the sovereign or were characterized by his control over the town by the 13th century at the latest. However, Krumau was the urban centre of an impressive and powerful

\footnotetext{
54 Oexle, "Gegenwart", 20-29; Borgolte, "Stiftungen", 267-85; Geary, Memory.

55 For the Austrian region two studies on urban foundations should primarily be mentioned: Pohl-Resl, Wiener Bürgerspital; Holzner-Tobisch, Seelenheilstiftungen.

56 Lusiardi, Stiftung, 13; Oberste, "Macht und Memoria", 25-48.

57 The sources refer to the towns by German names and for readability these are used in the text. For the first mention the current Czech name is given.
} 
manorial estate belonging to the noble Rosenberg family. 58 Budweis had been founded by King Přemysl Ottokar of Bohemia as a political and economic counterweight to the Austrian Freistadt. ${ }^{59}$ We therefore have to take a close look at a region in which several influential political forces were active: the king of Bohemia, the duke of Austria, and the Rosenberg family in South Bohemia - but also the Schaunberg family in Upper Austria, which sometimes decided to change sides as needed. The monasteries of the region played an important part in the noble and increasingly also urban culture of memory: above all the Cistercian abbeys of Baumgartenberg in Austria and Vyšši Brod/ Hohenfurt and Zlata Koruna/Goldenkron in South Bohemia. ${ }^{60}$

The construction of the town of Krumau began in the second half of the 13th century. Although there was already a town magistrate by the end of the 13th century, the town administration only became well established after the first third of the 14th century. Since the beginning of this century, the town had been owned by the Rosenberg family, who quickly transferred its powerbase to Krumau, developing it into a manorial residence and arranging the construction of the parish church of St. Vitus. The foundation of a monastery of the Poor Clares and of the Franciscan friary in the middle of the 14th century were also important for the town lord, who donated liberally to these religious institutions. Krumlov reached the apex of its development in the second half of the 15th century. As Krumau-like Budweis - stayed loyal to the Catholic party during the Hussite Wars, the town repeatedly became the target of Hussite attacks. ${ }^{61}$ The castle and the residence of the Rosenberg family, however, remained a safe place of refuge for the Catholics in difficult times. The archive of Goldenkron contains an inventory of the treasures from Goldenkron and the religious houses of Krumau and other monasteries and churches, which were brought to the castle of Kruman in 1418: relics, chalices, crosses, monstrances, liturgical vestments and books, as well as a detailed register of privileges were safely stowed away there. ${ }^{62}$

$5^{8}$ Semotanová, ed., Český Krumlov; Šimůnek, “Česky Krumlov", 475-520; Cechura, Grundherrn.

59 Dvořák, ed., České Budějovice.

6o For an overview of the Bohemian towns, see: Kuča, "Města”; Bahlcke et al., eds., Böhmen und Mähren; Žemlička, "Böhmen"; for an overview of the Bohemian monasteries see Lutter, "Vita Communis", in this volume, 367-68. Johanek, "Städtelandschaft", 295-316; Lomickova, "Visitationsurkunden", 241-82.

61 Šmahel, Die hussitische Revolution; Fudge, Heresy and Hussites; for Austria see Petrin, Hussitenkrieg; Stöller, "Hussiten", 1-87, lists different sources: charters and chronicles of Bohemian, Moravian and Austrian origin. For the military and political impact on Austria see Niederstätter, Jahrhundert, 343-46.

62 Schmid/Picha, eds., Urkundenbuch Krumau, 1:176 no. 657 . 
The rebuilding of the town during the mid-15th century was impressive: by granting commercial privileges, changing the course of trade routes, and intensifying the town's internal administration (drawing up last wills, keeping town records, and issuing town ordinances) the manorial residential town gained supraregional importance. ${ }^{63}$ Due to this revaluation of the urban polity, the citizens of the town also came to the fore. This is exemplified, among other things, by the increasing number of records of citizens' donations and by formal regulations concerning the disposition of last wills. Apart from the two hospitals and the Poor Clares' convent, the altar benefices of the town's parish church of St Vitus played a central role. All these institutions had been founded and endowed by members of the Rosenberg family. A number of Krumau citizens are recorded in the necrology of the Poor Clares' convent. Moreover, citizens from other cities are mentioned, like several merchants from Krems/Danube or the citizen Wenzel Zinespan from Freistadt, who made a donation to the nearby monastery too. His family was a long-term follower of the Rosenbergs. ${ }^{64}$

The situation in Budweis is different concerning the relationship between town dwellers and the town lord. ${ }^{65}$ Already in the middle of the 13th century, the king of Bohemia had founded the Goldenkron Cistercian monastery. Soon afterwards, he constructed the town of Budweis. Both of them constituted new centres of royal power in a region strongly influenced by the nobility, far from the centre of power in Prague. During the town's reconstruction after the damage caused by the Hussite wars, the Dominican monastery was founded and the St Nicholas Church was built. By the middle of the 14th century, the town had already received economic privileges, including the right to force merchants travelling from the Austrian town of Freistadt to stop at Budweis. The close economic contacts were also evident in other contexts as well, for example when the judge and the town council of Budweis confirmed that Thomas of Linz had donated to various altars in the Budweis parish church. Consulting the town's collection of documents, which provide information on various legal transactions until the end of the 14th century, one notices the large number of citizens' donations. The hospital had been founded by Zacharias, a burgher of Budweis, and numerous altars of the town's parish church also had been donated by burghers. The common interest of these urban communities

63 Semotanová, Český Krumlov; Šimůnek, “Town”, 168-71.

64 Basic research on the noble Zinespan family—among others-was carried out by Klaus Birngruber within the FWF-funded project Adel, Burg und Herrschaft im Mühlviertel, Oberösterreich (11.-14. Jahrhundert), (FWF P20416, project leader Karl Brunner); results will be published.

65 Dvořák, ed., České Budějovice. 
is obvious in this context. The existing donations were constantly added to, and the community of people who felt connected to them increased. All in all, records of testamentary donations for Budweis are more frequent than in Krumau. In the period between 1251 and 1391, ten per cent of the 543 registered documents are testamentary donations and donations for the salvation of souls. ${ }^{6}$

The Austrian town of Freistadt assumed a position similar to that of Budweis in economic and political terms. ${ }^{67}$ Owned by the duke, the town close to the border with Bohemia was the "long arm" of the Austrian dukes. When the enlargement of the ducal castle and town into a border fortress took place in the 14th century, there was already a functioning municipality with a range of economic privileges. The parish church of St Catherine and its numerous altars were the centre of civic remembrance, as were the civic hospital and the town hall. Surprisingly, in Freistadt there are no monasteries. Of the seventeen last wills and approximately 60 deeds of endowment, twenty contain donations to various altars in the parish church of St Catherine, and sixteen to the civic hospital or its Church of Our Lady. ${ }^{68}$ The remaining donations were given to various institutions, including the hospital (to provide the care of poor people), the Corpus Christi confraternity, and St Peter's chapel, founded by an influential burgess family. The nearby Cistercian abbey of Hohenfurt, however, received donations from Freistadt citizens only sporadically. ${ }^{69}$ It was the private monastery of the Rosenberg family. Apart from these gifts to recipients in the town, the donations from Freistadt families were rather given to the Cistercian monastery of Baumgartenberg, located near the Danube, dating from the 12th century and endowed by a noble family that had since vanished.

At the end of the 15th century, the widow Anna Zinespan, formerly married into an influential family of Freistadt, dictated her last will and took measures to secure her memoria. The family had founded the All Saint's benefice in St Peter's chapel on the hill, and remained its patrons. Furthermore, its members were affiliated to the prayer confraternity in the Krumau monasteries. They donated to the hospital Church of Our Lady and bequeathed their residence in Freistadt to St Catherine's Church for financing memorial services for themselves, their ancestors and descendants and all the souls. Apart from this, the family also had other means to keep its memory alive. The city lords of Krumau, Budweis and Freistadt pursued different interests in terms both of

\footnotetext{
66 Köpl, ed., Urkundenbuch Budweis.

67 Opll, Freistadt; Opll, "Anfänge", 79-94; Gruber, Freistadt, cf. 13-25.

68 Gruber, "Memoria", 31-50, with material on Freistadt.

69 Pangerl, ed., Urkundenbuch Hohenfurt.
} 
economic and political function. In this context, burghers could use their influence to establish and strengthen their impact on municipal autonomy. This is also reflected in the choice of religious institutions. As an individual undertaking, donating liturgical instruments, large sums of money, and valuable objects demonstrated a sense of social belonging. Contributions to the common good could only maintain their function as long as the social mechanisms of the donating community continued to function. Adding donations to existing ones, as well as periodic updating of the donation records and rentrolls by the donation's recipients, were both instrumental in the long-term and everlasting impact on the community's common good. Analysing these various forms of social mechanisms for an entire region gives us insights into the interplay between individuals and groups and their political and economic interdependencies. It can be observed that noble, urban and spiritual milieus refer to each other within the scope of their regional and societal influence. The example of this Central European region showed that every particular urban community developed a self-image dependent both on its legal and economic options as well as on the influence of the town's lord. The council and the townspeople were both entitled and responsible to protect the city as a legal and peace district (Friedensbezirk). Moreover, the urban elite was closely intertwined with the religious institutions, and they provided for the maintenance of the spiritual community. The example showed that in times of conflict or crisis existing groups were activated to secure the community's memory. But it also could have happened that new groupings, alliances, and oppositions were established within this framework. Yet, further research has to be done in the regional and supra-regional context. Nevertheless, it was clearly possible for contemporaries to question existing notions of community and to develop new ones, without questioning their urban community as such. They made use of proven models to express their internal but also external bonds. We also learned from this example, that there were spatial relations not only within the town but also established and maintained beyond it. These extended beyond social bonds within specific social groups-at least in the case of memorial practice.

As Oliver Schmitt argues in his paper on late medieval Dalmatian urban communities, "addressing community in the sense of defining community, defining rules and delimitations of belonging are [...] a key pattern of social life".70 This is true for the Dalmatian towns, but has also to be examined for the Austrian towns and their environments. Research on the groups' organization, implementation and maintenance in urban areas is a possibility for successfully

70 Schmitt, "Addressing community", in this vol. 25-47, cf. 29. 
pursuing various groupings within the town and the strategies used to establish, address, and secure community - at least in European urban contexts. Further studies also have to be carried out at a comparative level within the VISCOM project, based on the question of how social and spatial boundaries are established, committed or overcome and what role social bonds, such as family patterns, kinship or religious affiliations play in these very different regional, political, but also social contexts.

\section{Bibliography}

Paul J. Archambault, ed., A Monk's Confession: The Memoirs of Guibert of Nogent (Philadelphia, 1996).

Peter Arnade, Martha Howell and Walter Simons, "Fertile Spaces: The Productivity of Urban Space in Northern Europe", Journal of Interdisciplinary History 32 (2002), 515-48.

Joachim Bahlcke, Winfried Eberhard and Miloslav Polivka, eds., Böhmen und Mähren, Handbuch der historischen Stätten (Stuttgart, 1998).

Wim Blockmans, "Constructing a sense of community in rapidly growing European cities in the eleventh to thirteenth centuries", Historical Research 83, 222 (2010), 575-87; DOI: 10.1111/j.1468-2281.2010.00553.x.

Marc Boone, "Cities in late medieval Europe: The promise and the curse of modernity", Urban History 39 (2012), 329-49.

Michael Borgolte, "Stiftungen des Mittelalters im Spannungsfeld von Herrschaft und Genossenschaft", in Memoria in der Gesellschaft des Mittelalters, eds. Dieter Geuenich and Otto Gerhard Oexle, Veröffentlichungen des Max Planck Instituts für Geschichte 111 (Göttingen, 1994), 267-85.

Pierre Bourdieu, "The forms of capital", in Handbook of Theory and Research for the Sociology of Education, ed. John G. Richardson (New York, Greenwood, 1986), 241-58.

Jaroslav Cechura, Adelige Grundherrn als Unternehmer: Zur Struktur südböhmischer

Dominien vor 1620, Sozial- und wirtschaftshistorische Studien 25 (Vienna, Munich, 2000).

Jacques Chiffoleau, La comptabilité de l'au-delà: les hommes, la mort et la religion dans la région d'Avignon à la fin du Moyen Âge (vers 1320-vers 1480) (Paris, 2011).

Peter Clark, "Introduction", in The Oxford Handbook of Cities in World History, ed. Peter Clark (Oxford, 2013), 1-24.

Peter Csendes, Das Wiener Stadtrechtsprivileg von 1221 (Vienna, 1987).

Peter Csendes, "Regensburg und Wien-Babenbergerresidenzen des 12. Jahrhunderts", Jahrbuch des Vereins für Geschichte der Stadt Wien 47/48 (1991/1992), 163-71. 
Peter Csendes, "Das Werden Wiens-die siedlungsgeschichtlichen Grundlagen", in Peter Csendes and Ferdinand Opll, Wien: Geschichte einer Stadt. 1: Von den Anfängen bis zur Ersten Wiener Türkenbelagerung (1529) (Vienna, 2001).

Peter Csendes, "Die burgenses von St. Pölten und ihr Recht”, in St. Pölten im Mittelalter. Historische und Archäologische Spurensuche. Referate der gleichnamigen Tagung am 29. Okober 2009 in St. Pölten, ed. Heidemarie Bachhofer (St Pölten, 2012), 79-84.

Heide Dienst, "Das Privileg Bischof Konrads II. von Passau für die St. Pöltner Bürger vom 3. Mai 1159", in Sant Ypoelten. Stift und Stadt im Mittelalter: Katalogbuch zur Sonderausstellung des Diözesanmuseums St. Pölten aus Anlass der Verleihung des Privilegs von 1159 (St Pölten, 2009), 79-86.

Bernhard Diestelkamp, "Freiheit der Bürger-Freiheit der Stadt", in Die abendländische Freiheit vom 10. zum 14. Jahrhundert: Der Wirkungszusammenhang von Idee und Wirklichkeit im europäischen Vergleich, ed. Johannes Fried, Vorträge und Forschungen 39 (Sigmaringen, 1991), 485-510.

Jiří Dvořák, ed., České Budějovice: Historický atlas měst České republiky [České Budějovice: Historic Town Atlas of the Czech Republic] (Prague, 1996).

Edith Ennen, Die europäische Stadt des Mittelalters, 3rd ed. (Göttingen, 1979).

Erwin Frauenknecht, "Der Bischof und die Stadt: Ein Spannungsverhältnis zwischen geistlicher Intensität und weltlicher Aktivität”, in Geschichte der Stadt Regensburg, 2, ed. Peter Schmid (Regensburg, 2000), 688-709.

Heinrich Fichtenau and Erich Zöllner, eds., Urkundenbuch zur Geschichte der Babenberger in Österreich, 1: Die Siegelurkunden der Babenberger bis 1215, Publikationen des Instituts für Österreichische Geschichtsforschung 3/1 (Vienna, 1950).

Thomas A. Fudge, Heresy and Hussites in Late Medieval Europe, Variorum Collected Studies Series 1044 (Farnham 2014).

Patrick J. Geary, Phantoms of Remembrance: Memory and Oblivion at the End of the First Millennium (Princeton, 1994).

Elisabeth Gruber, "Memoria-bürgerliches Selbstverständnis im späten Mittelalter und in der frühen Neuzeit am Beispiel Freistadt", in Stadtkultur-Kultur(haupt) stadt, eds. Ferdinand Opll and Walter Schuster (Linz, 2012), 31-50.

Elisabeth Gruber, "Wer regiert hier wen? Handlungsspielräume in der spätmittelalterlichen Residenzstadt Wien", in Mittler zwischen Herrschaft und Gemeinde: Die Rolle von Funktions- und Führungsgruppen in der mittelalterlichen Urbanisierung Zentraleuropas, eds. Elisabeth Gruber, Susanne Pils et.al., Forschungen und Beiträge zur Wiener Stadtgeschichte 56 (Wien, 2013), 9-48.

Elisabeth Gruber, Formen kommunaler Rechnungspraxis im oberösterreichischen Freistadt. Edition und Kommentar der Stadtgrabenrechnung von 1389-1392, Quelleneditionen des Instituts für Österreichische Geschichtsforschung 14(Vienna, 2015). Elisabeth Gruber and Susana Zapke, A Companion to Medieval Vienna (1250-1529) (Leiden, forthcoming). 
Karl Gutkas, "Das österreichische Städtewesen im Mittelalter", in Die mittelalterliche Städtebildung im südöstlichen Europa, ed. Heinz Stoob, Städteforschung, Veröffentlichungen des Instituts für vergleichende Städtegeschichte in Münster Reihe A/4, (Cologne, Vienna 1977) 134-63.

Karl Gutkas, "König Ottokars Städtepolitik in Österreich und in der Steiermark", in Böhmisch-österreichische Beziehungen im 13. Jahrhundert: Österreich (einschließlich Steiermark, Kärnten und Krain) im Großreichprojekt Ottokars II. Přemysl, König von Böhmen. Vorträge des internationalen Symposions vom 26. bis 27. September 1996 in Znaim, eds. Marie Bláhová and Ivan Hlavácek (Prag, 1998), 107-25.

Alfred Haverkamp, "Bruderschaften und Gemeinden im 12. und 13. Jahrhundert", in Ordnungskonfigurationen im hohen Mittelalter, eds. Bernd Schneidmüller and Stefan Weinfurter (Ostfildern, 2006), 153-92.

Kornelia Holzner-Tobisch, Investitionen für die Ewigkeit: Die Seelenheilstiftungen in den letztwilligen Verfügungen der Stadt Korneuburg im 15. Jahrhundert, Medium Aevum Quotidianum Sonderband 19 (Krems, 2007).

Martha C. Howell, The marriage exchange: property, social place, and gender in cities of the Low Countries, 1300-1500 (Chicago, 1998).

Eberhard Isenmann, "The notion of the Common Good, the concept of politics, and practical policies in late Medieval and Early Modern German Cities", in De Bono Communi: The Discourse and Practice of the Common Good in the European City (12th-16th c.); Discours et pratique du Bien Commun dans les villes d'Europe (XIIIe au XVIe siècle), eds. Elodie Lecuppre-Desjardin and Anne-Laure Van Bruaene, Studies in European Urban History (1100-1800) 12 (Turnhout, 2010), 107-48.

Eberhard Isenmann, Die deutsche Stadt im Mittelalter 1150-1550 (Vienna, 2012).

Hermann Jakobs, "Stadtgemeinde und Bürgertum um 1100", in Beiträge zum Hochmittelalterlichen Städtewesen, ed. Bernhard Diestelkamp, Städteforschung A 11 (Cologne, 1982), 14-54.

Gabriele Jancke and Daniel Schläppi, “Ökonomie sozialer Beziehungen: Wie Gruppen in frühneuzeitlichen Gesellschaften Ressourcen bewirtschaften”, L'Homme: Europäische Zeitschrift für feministische Geschichtswissenschaft 22,1 (2011), 85-97.

Peter Johanek, "Die Entstehung der südböhmischen Städtelandschaft", in Zentrum und Peripherie in der Germania Slavica: Beiträge zu Ehren von Winfried Schich, ed. Doris Bulach (Stuttgart, 2008), 295-316.

Bernhard Jussen, "Perspektiven der Verwandtschaftsforschung fünfundzwanzig Jahre nach Jack Goodys 'Entwicklung von Ehe und Familie in Europa', in Die Familie in der Gesellschaft des Mittelalters, ed. Karl-Heinz Spieß (Ostfildern, 2009), 275-324.

Reinhold Kaiser, "Guibert de Nogent und der Bischofsmord in Laon (1112)", in Bischofsmord im Mittelalter: Murder of Bishops, eds. Natalie Fryde and Dirk Reitz, Veröffentlichungen des Max-Planck-Instituts für Geschichte 191 (Göttingen, 2003), $121-58$. 
Willibald Katzinger, ed., Elenchus fontium historiae urbanae, 3/1 (Leiden, New York, Cologne, 1992).

Martha Keil, ed., Besitz, Geschäft und Frauenrechte: Jüdische und christliche Frauen in Dalmatien und Prag 1300-16oo (Kiel, 2011).

Herbert Knittler, “Zum Problem des bürgerlichen Untertanenbesitzes auf dem Lande:

Die landesfürstlichen Städte ob der Enns und des Viertels ober dem Manhartsberg (NÖ) im Vergleich", in Zwischen Land und Stadt. Wirtschaftsverflechtungen von ländlichen und städtischen Räumen in Europa 1300-16oo, eds. Markus Cerman and Erich Landsteiner, Jahrbuch für Geschichte des ländlichen Raumes 6, 2009 (Innsbruck, 2010), 91-121.

Herbert Knittler, "Städtelandschaften in Österreich im Spätmittelalter und in der Frühen Neuzeit", in Städtelandschaft. Réseau Urbain. Urban Network: Städte im regionalen Kontext in Spätmittelalter und Früher Neuzeit, eds. Holger Thomas Gräf and Katrin Keller, Städteforschung A 62 (Cologne, 2004), 111-33.

Karl Köpl, ed., Urkundenbuch der Stadt Budweis in Böhmen 1251-1391, Städte- und Urkundenbücher aus Böhmen 4 (Prague, 1901).

Karel Kuča, Města a městečka v Čechách, na Moravě a ve Slezsku 1-8 [Städte und Ortschaften in Böhmen, Mähren und Schlesien] (Prague, 1996-2011).

Hans Lentze, "Das Wiener Testamentsrecht. 1 und 2. Teil", Zeitschrift der SavignyStiftung für Rechtsgeschichte 69 (1952), 98-154; 70 (1953), 159-229.

Klaus Lohrmann, Grundbücher, Veröffentlichungen des Wiener Stadt- und Landesarchivs Reihe A, Archivinventar: Serie 1, Stadtarchiv 2 (Vienna, 1986).

Klaus Lohrmann and Ferdinand Opll, eds., Regesten zur Frühgeschichte von Wien, Forschungen und Beiträge zur Wiener Stadtgeschichte 10 (Vienna, 1981).

Radka Lomickova, "Visitationsurkunden aus böhmischen und österreichischen Zisterzienserklöstern: Das Leben hinter Klostermauern im 14. Jahrhundert”, Citeaux - commentarii cistercienses, 62,1-4 (2011), 241-82.

Ralf Lusiardi, Stiftung und städtische Gesellschaft: Religiöse und soziale Aspekte des Stiftungsverhaltens im spätmittelalterlichen Stralsund, Stiftungsgeschichten 2 (Berlin, 2000).

Christina Lutter, "Social Groups, Personal Relations, and the Making of Communities in Medieval vita monastica", in Making Sense as Cultural Practice: Historical Perspectives, eds. Jörg Rogge et al., Mainzer Historische Kulturwissenschaften 17 (Bielefeld, 2013), 45-64.

Christina Lutter, "Comparative Approaches to Visions of Community", History and Anthropology26 (2015), 129-43. http://dx.doi.org/10.108o/02757206.2014.930738.

Christian Neschwara, "Rechtsformen letztwilliger Verfügungen in den Wiener Stadtbüchern (1395-1430): Eine Bilanz aufgrund der vorliegenden Edition”, in Testamente aus der Habsburgermonarchie: Alltagskultur, Recht, Überlieferung, ed. Thomas Olechowski and Christoph Schmetterer, Beiträge zur Rechtsgeschichte Österreichs 1 (Vienna, 2011), 131-47. 
Alois Niederstätter, DasJahrhundert der Mitte:An der Wende vom Mittelalter zur Neuzeit 1400-1522, Österreichische Geschichte (Wien, 1996).

Jörg Oberste, "Macht und Memoria: Religiöses Leben und soziale Netzwerke des Regensburger Patriziates im späteren Mittelalter", in Regensburg im Spätmittelalter, ed. Peter Schmid, Forum Mittelalter-Studien 2, (Regensburg, 2007), 25-48.

Otto G. Oexle, "Die Gegenwart der Toten", in Death in the Middle Ages (Leuven, 1983), 20-77; repr. in id., Die Wirklichkeit und das Wissen: Mittelalterforschung — historische Kulturwissenschaft — Geschichte und Theorie der historischen Erkenntnis (Göttingen, 2011), 99-155.

Ferdinand Opll, "Die Anfänge der Stadt Freistadt", Jahrbuch des oberösterreichischen Musealvereins 134,1 (1989), 79-94.

Ferdinand Opll, Freistadt, Österreichischer Städteatlas. 4. Lieferung, 1. Teil (Vienna, 1991). Ferdinand Opll, "Stadt und Region: Internationale Forschungen und Perspektiven", in Zur österreichischen Stadtgeschichtsforschung: Bilanz und Perspektiven, Stadt und Region. Internationale Forschungen und Perspektiven. Kolloquium für Peter Johanek, eds. Heinz Duchhardt and Eberhard Reininghaus (Köln, 2005), 43-72.

Mathias Pangerl, ed., Urkundenbuch des Cistercienserstiftes B. Mariae V. zu Hohenfurth in Böhmen (Wien, 1865).

Michel Pauly and Martin Scheutz, "Space and history as exemplified by urban history research", in Cities and their Spaces: Concepts and their use in Europe, eds. Michel Pauly and Martin Scheutz, Städteforschung A 88 (Cologne, 2014), $15^{-28 .}$

Silvia Petrin, Der österreichische Hussitenkrieg 1420-1434 (Vienna, 1982).

Gerhard Pferschy, “Ottokar II. Přemysl, Ungarn und die Steiermark”, in OttokarForschungen, ed. Maximilian Weltin, Jahrbuch für Landeskunde von NÖ. N.F. 44/45 (Vienna, 1979), 73-91.

Brigitte Pohl-Resl, Rechnen mit der Ewigkeit: Das Wiener Bürgerspital im Mittelalter, Mitteilungen des Instituts für Österreichische Geschichtsforschung, Ergänzungsband 33 (Vienna, 1996a).

Brigitte Pohl-Resl, "Family, Memory and Charity in Late Medieval Vienna", Medium aevum quotidianum 35 (Krems 1996b), 125-32.

Susan Reynolds, Kingdoms and Communities in Western Europe 900-130o (Oxford, 1997).

Susan Reynolds, The Middle Ages without Feudalism: Essays in Criticism and Comparison on the Medieval West, Variorum collected studies series 1019 (Farnham, 2012).

Walther Rösener, "Grundherrschaft, II. Deutschland/Mitteleuropa", in Lexikon des Mittelalters, 10 vols. (Stuttgart, 1977-1999), 4:cols. 1746-47, Brepolis Medieval Encyclopaedias - Lexikon des Mittelalters Online.

Jörg Rogge, Für den gemeinen Nutzen: Politisches Handeln und Politikverständnis von Rat und Bürgerschaft in Augsburg im Spätmittelalter, Studia Augustana 6 (Tübingen, 1996). 
David Warren Sabean and Simon Teuscher, "Kinship in Europe: A New Approach to Long-Term Development", in Kinship in Europe: Approaches to long-term development (1300-190o), eds. David Warren Sabean and Simon Teuscher (New York, 2007), $1-32$.

Georg Scheibelreiter, "Zur Typologie und Kritik genealogischer Quellen”, in Wappenbild und Verwandtschaftsgeflecht: Kultur- und mentalitätsgeschichtliche Forschungen zu Heraldik und Genealogie, ed. Georg Scheibelreiter, Mitteilungen des Instituts für Österreichische Geschichtsforschung, Ergänzungsband 53 (Vienna, 2009), 287-310.

Peter Schmid, "Die Herrschaftsträger und ihre Einflußsphären im früh- und hochmittelalterlichen Regensburg", in Regensburg im Mittelalter, 1: Beiträge zur Stadtgeschichte vom frühen Mittelalter bis zum Beginn der Neuzeit, ed. Martin Angerer (Regensburg, 1998), 45-56.

Valentin Schmid and Alois Picha, eds., Urkundenbuch der Stadt Krumau in Böhmen, 1: 1253-1419, Städte- und Urkundenbücher aus Böhmen 5 (Prague, 1908).

Bernd Schneidmüller and Stefan Weinfurter, "Ordnungskonfigurationen: Die Erprobung eines Forschungsdesigns", in Ordnungskonfigurationen im hohen Mittelalter, ed. Bernd Schneidmüller and Stefan Weinfurter, Vorträge und Forschungen 64 (Ostfildern, 2006), 7-18.

Knut Schulz, "Denn sie lieben die Freiheit so sehr ...": Kommunale Aufstände und Entstehung des europäischen Bürgertums im Hochmittelalter (Darmstadt, 1992), 5-11. Knut Schulz, "Zensualen, Zinsleute, Zensualität", in Lexikon des Mittelalters, 10 vols. (Stuttgart, 1977-1999), 9:cols. 530-33, Brepols MedievalEncyclopaedias-Lexikon des Mittelalters online.

Knut Schulz, "Zensualität und Stadtentwicklung im 11./12. Jahrhundert”, in Beiträge zum Hochmittelalterlichen Städtewesen, ed. Bernhard Diestelkamp, Städteforschung A 11 (Cologne, 1982), 73-93.

Knut Schulz, "Von der familia zur Stadtgemeinde: Zum Prozeß der Erlangung bürgerlicher Freiheitsrechte durch hofrechtlich gebundene Bevölkerungsgruppen”, in Die abendländische Freiheit vom 10. zum 14. Jahrhundert: Der Wirkungszusammenhang von Idee und Wirklichkeit im europäischen Vergleich, ed. Johannes Fried, Vorträge und Forschungen 39 (Sigmaringen, 1991), 461-84.

Knut Schulz, "Die Urbanisierung Mitteleuropas im 12. und 13. Jahrhundert", in Die Urbanisierung Europas von der Antike bis in die Moderne, eds. Gerhard Fouquet and Gabriel Zeilinger, Kieler Werkstücke: Reihe E, Beiträge zur Sozial- und Wirtschaftsgeschichte 7 (Frankfurt am Main, 2009), 147-72.

Kerstin Seidel, Freunde und Verwandte: Soziale Beziehungen in einer spätmittelalterlichen Stadt (Frankfurt am Main, 2009).

Eva Semotanová, ed., Český Krumlov: Historický atlas měst České republiky 11 [Český Krumlov: Historic Town Atlas of the Czech Republic] (Prague, 2003). 
Gabriela Signori, Von der Paradiesehe zur Gütergemeinschaft: Die Ehe in der mittelalterlichen Lebens- und Vorstellungswelt (Frankfurt am Main, 2011).

Robert Šimůnek, "Česky Krumlov v 15. Století pozdně středověké město jako jeviště sakrální reprezentace" [Česky Krumlov in the 15th century: The late medieval city as stage of representation of the sacred], in Česky Krumlov: Od rezidenčního města k památce světového kulturního dědictví [Česky Krumlov: From Residential town to World Heritage Site] (Ceské Budějovice, 2010), 475-520.

Robert Šimůnek, "Town and its vicinity as spaces for sacral Representation, Bohema 1350-160o", in Cities and their Spaces: Concepts and their use in Europe, eds. Michel Pauly and Martin Scheutz, Städteforschung A 88 (Cologne, 2014), 167-81.

František Šmahel, Die hussitische Revolution 1-3 (Hanover, 2002).

Matthias Günter Steiner, Die Klöster und ihr Wirken-eine der Wurzeln des Stiftungswesens? Rechtshistorische Reihe 387 (Frankfurt am Main, 2009).

Ferdinand Stöller, “Österreich im Kriege gegen die Hussiten (1420-1436)", Jahrbuch für Landeskunde Niederösterreich N.F. 22 (1929), 1-87.

Katalin Szende, Otthon a városban: Társadalom és anyagi kultúra a középkori Sopronban, Pozsonyban és Eperjesen [At Home in the City: Society and material culture in medieval Sopron, Bratislava and Presov], Társadalom-és művelődéstörténet tanulmányok 32 (Budapest, 2004).

Simon Teuscher, Bekannte, Klienten, Verwandte: Soziabilität und Politik in der Stadt Bern um 1500 (Cologne, 1998).

Simon Teuscher, "Politics of Kinship in the City of Bern at the End of the Middle Ages", in Kinship in Europe: Approaches to long-term development (1300-19oo), eds. David Warren Sabean and Simon Teuscher (New York, 2007), 76-90.

Karl Uhlirz, ed., Quellen zur Geschichte der Stadt Wien, Abt. 2/1: Verzeichnis der Originalurkunden des Städtischen Archives 1239-1411 (Vienna, 1898).

Heinrich Wanderwitz, "Regensburg, ein früh- und hochmittelalterliches Handelszentrum", in Das mittelalterliche Regensburg im Zentrum Europas, ed. Edith Feistner (Regensburg, 2006), 43-54.

Herwig Weigl, "Städte und Adel im spätmittelalterlichen Österreich", in Oberdeutsche Städte im Vergleich: Mittelalter und Frühe Neuzeit, eds. Joachim Jahn, Wolfgang Hartung and Immo Eberl, Regio. Forschungen zur schwäbischen Regionalgeschichte 2 (Sigmaringendorf, 1989), 74-100.

Herwig Weigl, Materialien zur Geschichte des rittermäßigen Adels im südwestlichen Österreich unter der Enns im 13. und 14. Jahrhundert, Forschungen zur Landeskunde von Niederösterreich 26 (Vienna, 1991).

Maximilian Weltin, "Zur niederösterreichischen Stadtministerialität im 13. Jahrhundert (am Beispiel von Laa an der Thaya)", in Maximilian Weltin, Das Land und sein Recht: Ausgewählte Beiträge zur Verfassungsgeschichte Österreichs im Mittelalter, eds. 
Folker Reichert and Winfried Stelzer, Mitteilungen des Instituts für österreichische Geschichtsforschung, Ergänzungsband 49 (Vienna, 2006a), 9-23.

Maximilian Weltin, "Landesherr und Landherren: Zur Herrschaft Ottokars II. Premysl in Österreich", in Maximilian Weltin, Das Land und sein Recht: Ausgewählte Beiträge zur Verfassungsgeschichte Österreichs im Mittelalter, eds. Folker Reichert and Winfried Stelzer, Mitteilungen des Instituts für österreichische Geschichtsforschung, Ergänzungsband 49 (Vienna, 2006b), 130-87.

Dana Wessell Lightfoot, Women, Dowries and Agency: Marriage in Fifteenth-Century Valencia (Manchester, New York, 2013).

Alois Zauner, "Ottokar II. Přemysl und Oberösterreich", Ottokar-Forschungen, ed. Maximilian Weltin, Jahrbuch für Landeskunde von NÖ. N.F. 44/45 (Vienna, 1979), $1-72$.

Andreas Hermenegild Zajic, "Zu ewiger gedächtnis aufgericht": Grabdenkmäler als Quelle für Memoria und Repräsentation von Adel und Bürgertum im Spätmittelalter und in der Frühen Neuzeit. Das Beispiel Niederösterreichs, Mitteilungen des Instituts für Österreichische Geschichtsforschung, Ergänzungsband 45 (Vienna, 2004).

Josef Žemlička, "Böhmen-von den slawischen Burgzentren zum spätmittelalterlichen Städtenetz (mit Berücksichtigung Mährens)”, in Städtelandschaft-Städtenetzzentralörtliches Gefüge: Ansätze und Befunde zur Geschichte der Städte im hohen und späten Mittelalter, eds. Monika Escher, Alfred Haverkamp and Frank G. Hirschmann, Trierer Historische Forschungen 43 (Mainz, 2000), 233-54. 